\title{
CLICHE: Education Games for Climate Change Countermeasures
}

\author{
Fajar As'ari \\ Department of Information Systems, Faculty of Computer Science \\ Soegijapranata Catholic University (SCU), Semarang, Indonesia \\ asari.fajar@gmail.com \\ Viena Patrisiane \\ Business Analyst \\ PT. Visionet Data Internasional, Tangerang, Indonesia \\ tvxq_cho@yahoo.co.id
}

Abstract- Game as an education media can introduce, deliver and teach about knowledge by presenting the information that contains education materials through digital game. Many subjectshave been adapted game as a tool of media education, like history, arithmetic, etc. Social and environmental issues can also be adapted into a game to overcome the issues.

Climate change, a globally concerned issue, has been discussed in the aspects of causes and impacts. Minimizing behavior that can worsen climate change also means minimizing climate change effect. One of education games has been created to educate people about climate change, and to inform about climate change and the way to minimize the effects.

This paper will discuss about education games: CLICHE, a game which explains concisely the cause and some actions to minimize climate change cause through digital game play that will have impact to lessen the climate change effects.

Keywords: digital game, education games, climate change, simulation game.

\section{I.INTRODUCTION}

Many educational subjectshave been adapted into digital game. History is one of education topics that is already adapted into education games [1]. In addition to history, mathematics also can be adapted into a game for learning[2]. Using game as media makes students easier to understand the information that has been delivered through game.This game can be proved as an alternative to education media[1], [2].Because the benefit can be as education media, health education game can also be created to teach about appropriate health knowledge and good habits in daily life[3].Education about disaster with flood topic that is delivered through computer game was applied in Taiwan which was effectively teaching flood and the impact for young generations[4].

Climate change, which as a matter of fact climate on earth is not constant, could be warmer and cooler for thousands of years. However, in the past 100 years or so earth's climate is warmer with the average increase temperature more than one degree Fahrenheit. The amount that seems small can cause great impacts on Earth[5]. Impacts that cannot be underestimated makes climate change as global issues. The climate warming that causes temperature has obviously risen since 1950.This brings about impact on atmosphere and ocean, decreasing the amount of ice and snow, and the level of the sea that risen. Human influences through climate change are really obvious and impacts toward human and nature are widespread [6].From the impacts that appear, of course people should realize about climate change and participate in process to minimize impacts and cause of climate change.

Information about climate change has been delivered through some media to build 
awareness [7]. Game is one of media that can deliver the information. Delivering information about what causes climate change and about how to minimize the causes has been summarized into education media: CLICHÉ that will be explained in this paper.

\section{LITERATURE REVIEW \\ 2. 1 Climate Change}

Climate change occurs at the whole earth's climate, and causes earth's temperature increasing [5]. This temperature increase is caused by greenhouse gas (GHG) that accumulates since pre-industrial era, also by population and economic rapidly growth, which is higher than ever had. GHG consist of carbon dioxide (CO2), methane (CH4), and nitrous oxide (N4O). Earth's temperature escalation impacts on ecosystem and people over the world. However, the impacts worsenthe nature ecosystem. Change on climate system also melts ice that elevates the sea level that impacts on water ecosystem [6].

To prevent impacts get worse from climate change, action that is supposed to reduce GHG is required, for exampleusing energy as efficient as possible and using energy from the sun, wind, water, or other clean energy. Using less water, turning off the lamp and TV when leaving the room aresome steps to retrench energy. Besides that, reforestation and against deforestation to alleviate $\mathrm{CO} 2$ trapped in atmosphere are important.

\section{2 Education games}

The advanced computer technology produces a research to develop education media to improve students learning process. From several media, digital game has high potential to motivate students[3]. About motivation, education games with disaster theme successfully motivate the student to learn about flood through game-initiatedlearning (GIL)[4]. Content or subject that will be delivered through game is really important part for education process[3]. In education perspectives, game can be used as vehicle to deliver fact, idea, and to help students to reveal new knowledge[8].

\section{RESEARCH METHODOLOGY}

Literature review about climate change and education games has been done to strengthen the foundation about the game that will be discussed in this paper. Analyzing the game and gameplay has been done to explain some actions that will minimize climate change causes and impacts that are delivered through game CLICHÉ.

\section{RESULTS AND DISCUSSION}

CLICHÉ is an education game with theme about climate change that has purpose to raise awareness about the importance to minimize climate change causes and their impacts. This game has 5 levels, and in every level gives players different information for climate change countermeasure.

\subsection{Game start}

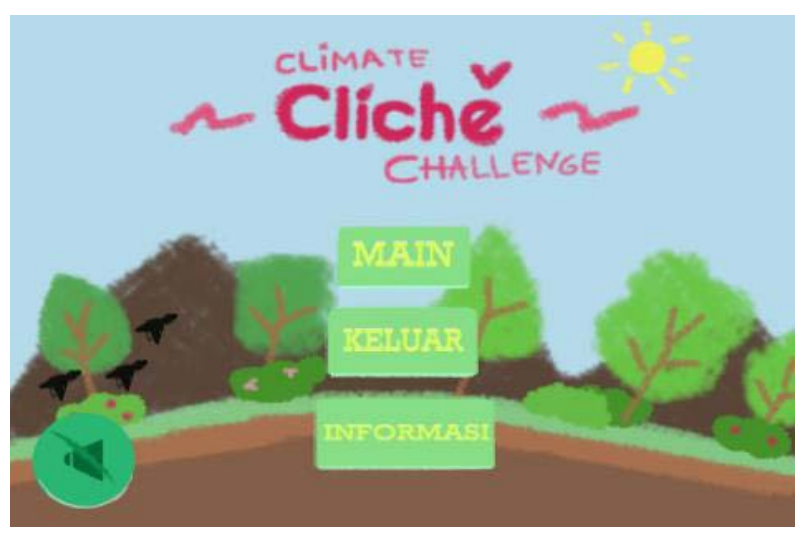

Fig 4. 1 Main menu game CLICHE

On game start, it will appear 3 menu choices: Main menu : go to level menu before play the game.

Keluar : quit from game application game CLICHÉ

Informasi : brief information about game CLICHE 


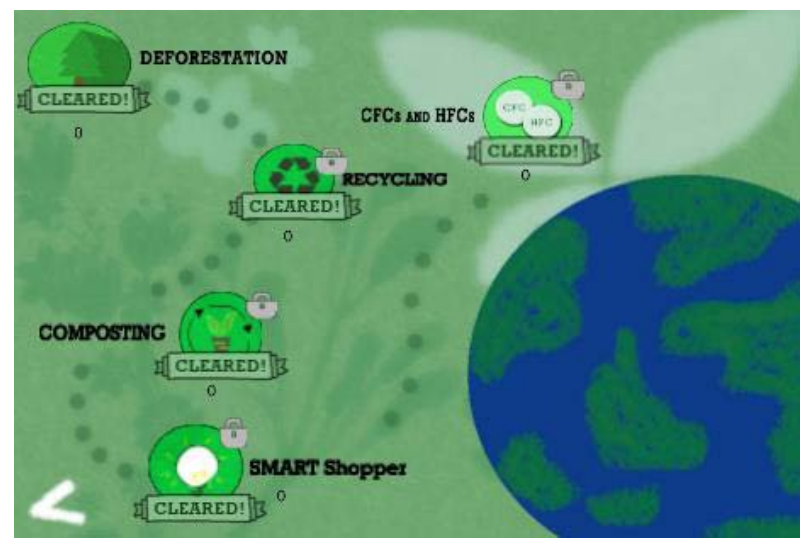

Fig 4. 2 Menu Level game CLICHE

Menu level consists of five levels that are related with climate change.

Level 1 : deforestation.

Level 2 : recycling

Level 3 : composting

Level 4 : smart shopper

Level 5 : CFCs and HFCs

In first game, level 2 till 5 are still locked and cannot be opened. To open level 2 players should complete level 1 ; to open level 3 players should complete level 2 and so on.

\subsection{Level 1}

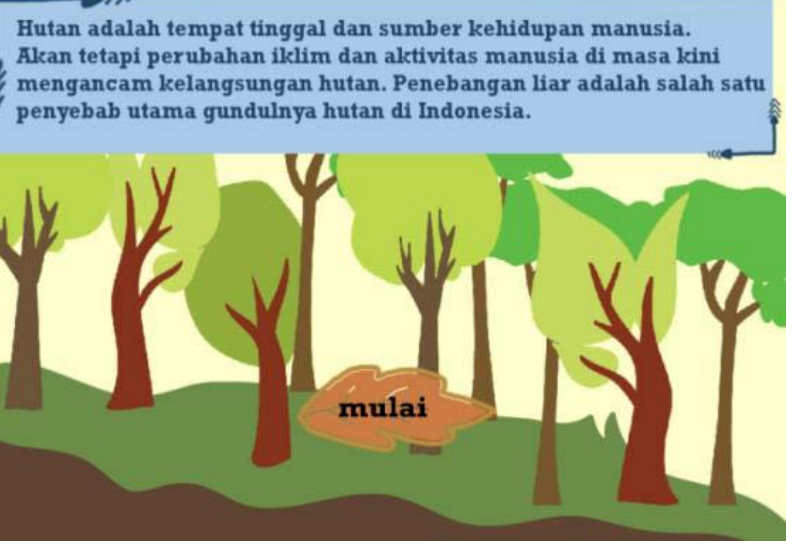

Fig 4. 3 Introduction level 1

Before level 1starts, it will appear information as opening thatis related with forest.

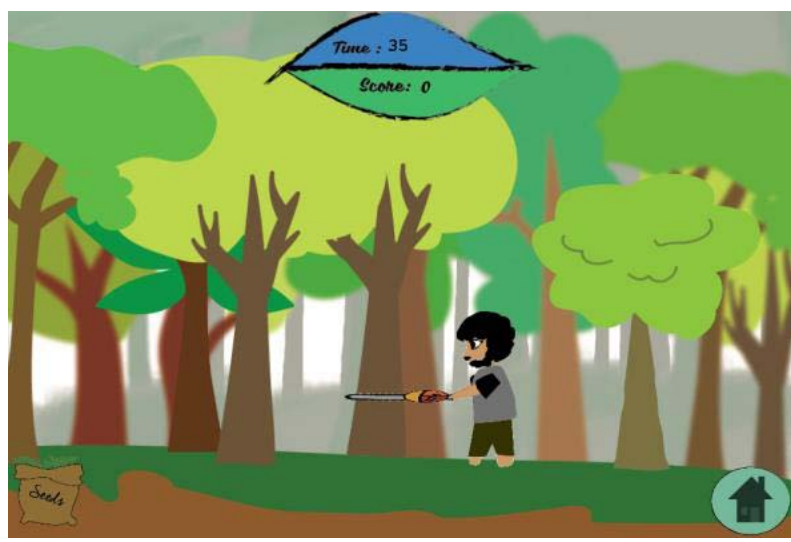

Fig 4. 4 Level 1 Game CLICHÉ

Deforestation is the topic that is adapted in this level. Deforestation which impacts on reducingtrees in forest causes $\mathrm{CO} 2$ that cannot be recycled into $\mathrm{O} 2$.

In this level, player asked to catch illegal logger before the tree fall. This level informs to prevent deforestation in order to not worsen the forest state.

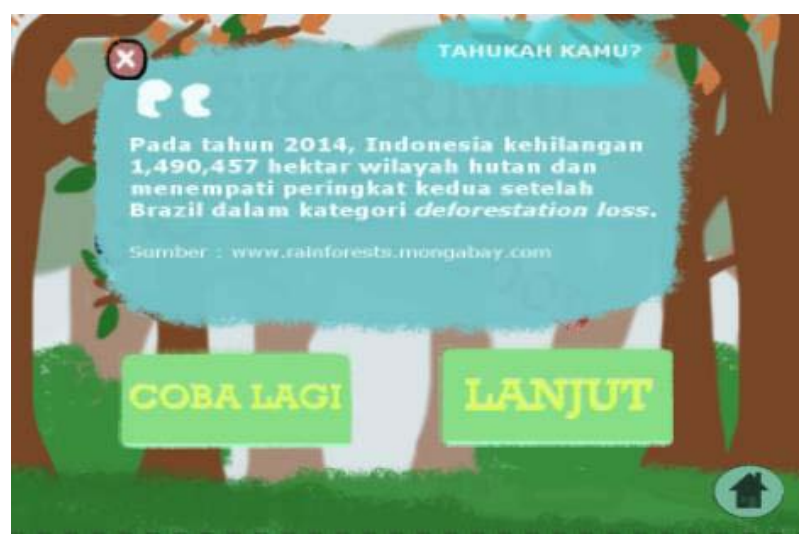

Fig 4. 5 Level 1 CLICHE game over

Level 1 that has time limits to play, when the time is up picture like Fig 4.5 will appear and give brief information about forest. Two-menu button is prepared to restart the level with button "coba lagi” or go to next level with button "lanjut” or proceed. 


\subsection{Level 2}

\section{LEVEL 2 : STAGE 1}

Drag \& drop sampah sesuai dengan kategorinya!
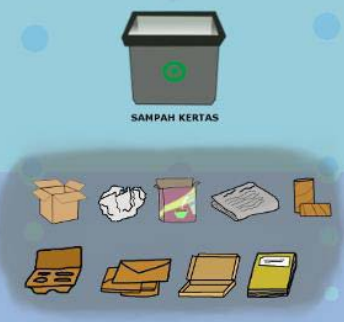

Fig 4. 6 Level 2 instructions

Before level 2 is played, instruction will appear to introduce player about waste paper type, and it should be put in grey trashcan or $\mathrm{HW} / \mathrm{RC}$ waste should be put in blue trashcan.

In this level, two waste types are shown to player in order to choose which one waste paper and HW/RC. Waste paper comprises newspaper, paper, cupboard, box pizza, tube tissue, cereal box, envelope, and egg board. Waste HW/RC is battery, log, wheel, brick, and plastic bottle.

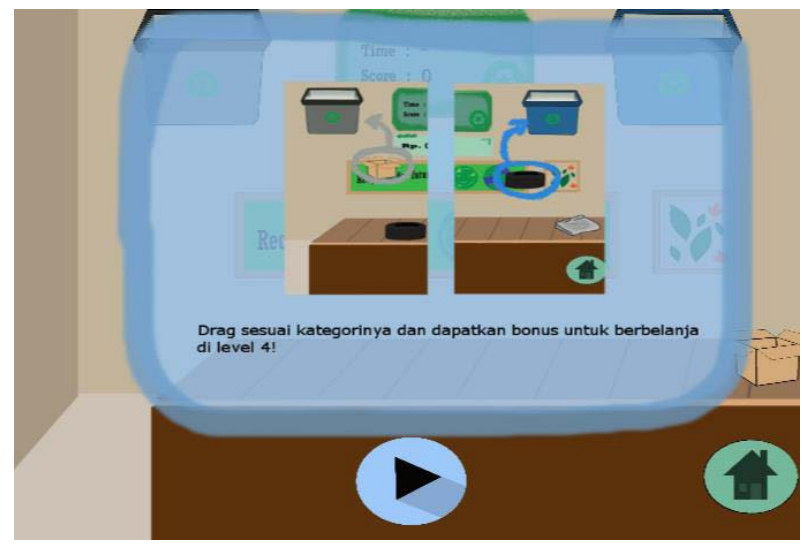

Fig 4. 7 Level 2 instructions (2)

Level 2 has two stages; every stage in this level has the same gameplay, the differenceon the difficulty level and waste that have various types. First stage, all the trash can be thrown into trashcan, however in second stage not all trash can be thrown into trashcan.
In this level, it also applies time limit;a player can get points if he/she puts trash in the right trashcan. Besides points, the player can also collect money and this money can be used in level 4.

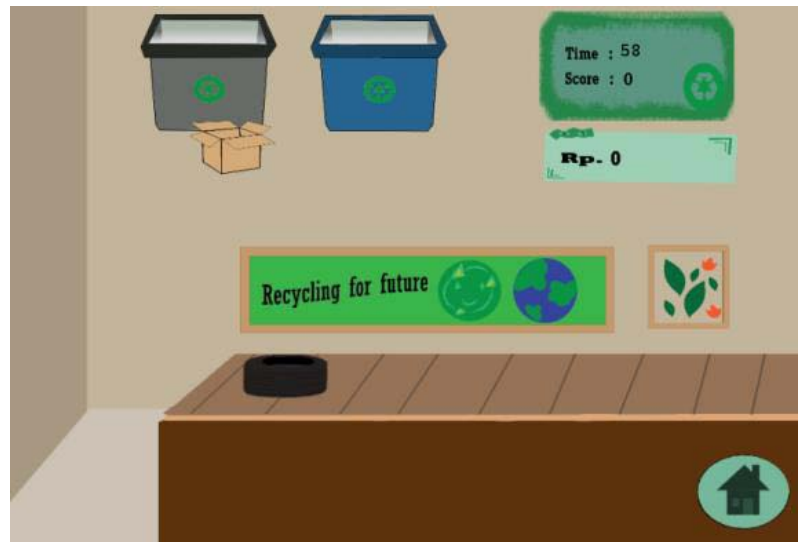

Fig 4. 8 Level 2 Game CLICHÉ

In level 2,the player learns to choose the trash that makes it easy to recycle or reuse so the trash not contaminate the environment.

\section{$4.4 \quad$ Level 3}

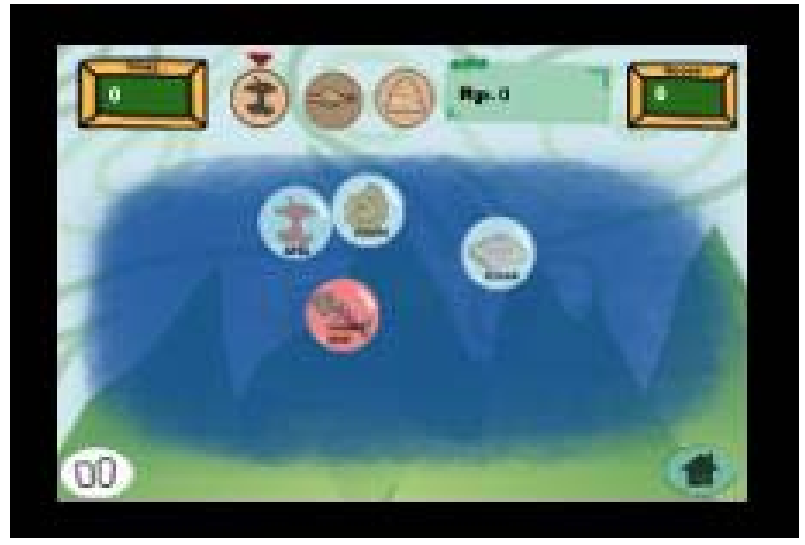

Fig 4. 9 Level 3 Game CLICHÉ

Composting, players are asked to choose compost materials that match with pictures next to scoreboard. Level 3 is continuation of level 2 about waste, if in level 2 about inorganic waste, in this level is about organic waste. Processing organic waste into compost has benefit instead of decreasing amount of 
waste also trash that has changed into compost that can be used as natural fertilizer.

\subsection{Level 4}

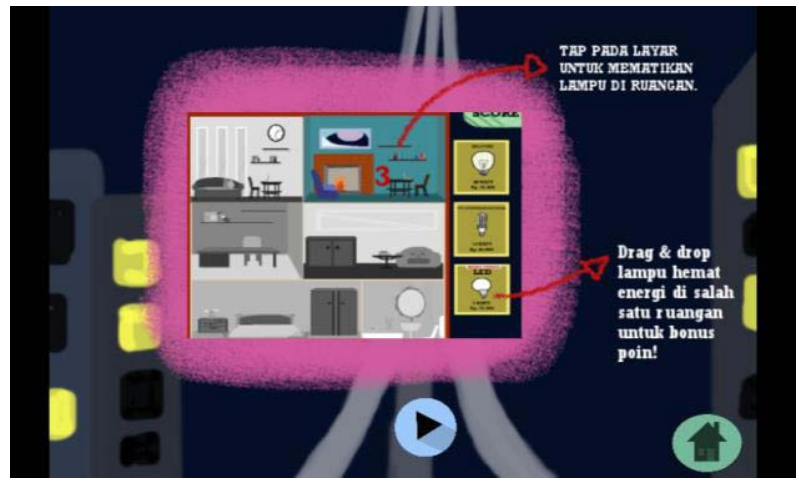

Fig 4. 10 Level 4 Game CLICHÉ

In level 2, in additionto points as feedback, players also get money that can be used in level 4. In level 4 players are directed to use less energy by turning off the lamp if there is no one in the room. Moreover, money that players have can be used to buy lamp if one lamp in the rooms is broken. Players can buy lamps and if player choose energy saving lamp player will get point bonus. To repair the broken lamp, players need to drag it and direct it into the new lamp.

Saving energy is a step to prevent climate change impacts get worse becausethe energy sourcesare from fossil or coals burnt that produce $\mathrm{CO} 2$.

\subsection{Level 5}

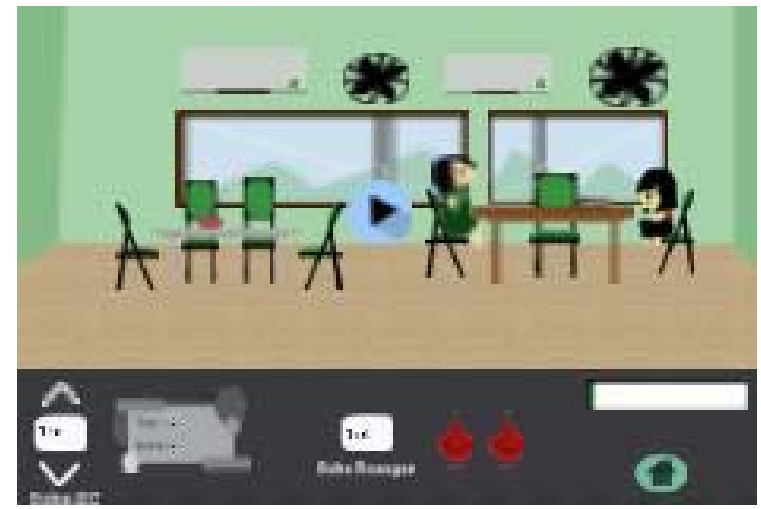

Fig 4. 11 Level 5 Game CLICHÉ
Level 5 is still related with level 4, but in this level player should control room temperature with considering the efficiency use of air conditioner (AC) and fan. This level informs players to use AC and fanwisely; it doesn't mean to turn off the $\mathrm{AC}$ but to arrange the $\mathrm{AC}$ temperature and fan to circulate AC cold air.

AC is one of household electronics that produces CFC/HFC part of GHG that cause climate change. After playing this level, a player is expected to wisely use household electronics that cause GHG to minimize causes of climate change.

\section{CONCLUSION}

Using game as education media can give positive impact for education itself. Giving motivation is one benefit of education games. Adapting global issues into a game to inform about the issues is also one of positive sides of education games.

CLICHÉ game adapts global issues as the main theme, climate change. CLICHÉ gives countermeasure information or prevents climate change from worsening. Consisting of five levels with each level has purpose to raise awareness that people can participate minimize causes of climate change. Level 1 is to prevent deforestation. Level 2 and 3 are about waste and recycling, reusing, and composting. Level 4 and 5 are about saving energy, informing about using less energy, using less fuel that can cause GHG.

\section{ACKNOWLEDGEMENT}

Fajar As'ari and Viena Patrisiane are Game Technology students of Soegijapranata Catholic University. Based on academic excellent, Fajar As'ari receives scholarship from Ministry of National Education of Republic Indonesia (Excellence Scholarship of Education Ministry of Republic of Indonesia) 


\section{REFERENCES}

[1] N. A. Wijaya and R. Sanjaya, "History Lesson using Game as the Tool," Int. J. Comput. Internet Manajement, vol. 19, no. 9, p. 6, 2012.

[2] V. W. Febriani and T. B. Chandrawati, "Shooting Game can be an Education games for Children,” no. February, pp. 23-24, 2012.

[3] H.-Y. Sung, G.-J. Hwang, and Y.-F. Yen, "Computers \& Education Development of a contextual decisionmaking game for improving students, learning performance in a health education course," Comput. Educ., vol. 82, pp. 179-190, 2015.

[4] M. Tsai, Y. Chang, C. Kao, and S. Kang, "The effectiveness of a flood protection computer game for disaster education,” 2015.
[5] D. Stillman and D. Miller, "What Are Climate and Climate Change?," www.nasa.gov, 2011. [Online]. Available:

https://www.nasa.gov/audience/forstude nts/5-8/features/nasa-knows/what-isclimate-change-58.html. [Accessed: 11Mar-2017].

[6] IPCC, “Climate Change 2014 Synthesis Report Summary Chapter for Policymakers,” 2014.

[7] V. Patrisiane, "Simulasi dan Penerapan Penanggulangan Perubahan Iklim Dengan Media Game,” Soegijapranata Catholic University, 2016.

[8] L. Botturi and C. S. Loh, Games : Purpose and Potential in Education, 1st ed. USA, New York: Springer Publishing Company, Inc., 2008. 